\begin{tabular}{lllllllll}
$\mathbf{A}$ & $\mathbf{R}$ & $\mathbf{T}$ & $\mathbf{Y}$ & $\mathbf{K}$ & $\mathbf{U}$ & $\mathbf{L}$ & $\mathbf{Y}$ \\
\hline
\end{tabular}

ROCZNIKI TEOLOGICZNE

Tom LXVIII, zeszyt $10-2021$

DOI: https://doi.org/10.18290/rt.216810.1

AGNIESZKA BOCHNIARZ

URSZULA OLEJNIK

\title{
SAMOPOCZUCIE RETROSPEKTYWNE I REALNE UCZNIÓW W CZASIE PANDEMII
}

\author{
RETROSPECTIVE AND REAL WELL-BEING OF STUDENTS DURING A PANDEMIC
}

A b s t r a c t. A positive state of mental, physical, and social well-being allows one to perceive life as fulfilling and happy. The transition of schools to a distance learning mode as a result of the SARS-CoV-2 coronavirus pandemic resulted in numerous challenging situations, and these situations affected the well-being of children and adolescents. The research undertaken aimed to determine the retrospective and real-world well-being of students. Moreover, the following variables were sought to be related to the level of well-being: gender, age, grade, place of residence, and material situation.

Keywords: well-being; remote education; psychological and pedagogical assistance; pandemic.

\section{WPROWADZENIE}

Epidemia koronawirusa (COVID-19) wymusiła inny model działania edukacji, prowadząc do ogromnych zmian w funkcjonowaniu wszystkich jej

Dr hab. AgniESZKa BochniARZ - Katedra Pedeutologii i Edukacji Zdrowotnej, Instytut Pedagogiki, Uniwersytet Marii Curie-Skłodowskiej; adres do korespondencji: 20-449 Lublin, ul. Sienkiewicza 25, e-mail: agnieszka.bochniarz@ mail.umcs.pl; ORCID: https://orcid.org/00000002-5675-3314.

Dr URSZUla OleJNIK - Katedra Pedeutologii i Edukacji Zdrowotnej, Instytut Pedagogiki, Uniwersytet Marii Curie-Skłodowskiej; adres do korespondencji: 21-132 Kamionka, Wólka Krasienińska 31; e-mail: urszula.olejnik@ @ail.umcs.pl; ORCID: https://orcid.org/0000-0003-2391-123X. 
podmiotów - nauczycieli, rodziców, a przede wszystkim uczniów. Dotychczasowa forma kształcenia, oparta na osobistym kontakcie nauczyciela z uczniami i uczniów ze sobą, zastąpiona została edukacją zdalną, która przestała być opcją a stała się codzienną praktyką, rozwiązaniem gwarantującym bezpieczeństwo dorosłych i dzieci. Realizacja edukacji w trybie zdalnym w nowej rzeczywistości stała się sporym wyzwaniem dla wszystkich jej uczestników przede wszystkim ze względu na ich zróżnicowane możliwości, chęci i kompetencje cyfrowe, zmuszając niektórych do przejścia przyspieszonego kursu korzystania z narzędzi cyfrowych.

Wprowadzenie licznych ograniczeń, samoizolacja i przedłużający się brak kontaktu z rówieśnikami na skutek zamknięcia szkół miały na celu ograniczyć dalszą transmisję wirusa, ale jednocześnie postawiły w psychologicznie trudnej sytuacji dzieci i młodzież. Po pierwszym etapie radości i zadowolenia młodzi ludzie musieli zmierzyć się z emocjami i problemami charakterystycznymi dla sytuacji kryzysowej. Samopoczucie jednostki w sytuacji kryzysowej determinowane jest przez trzy czynniki: kontekst społeczny, kontekst rodzinny oraz cechy osobowości. Ponadto każdy kryzys ma ograniczenia czasowe, jednak nie przepracowany może prowadzić do poważnych zaburzeń w zachowaniu ${ }^{1}$. Młode osoby stanowią grupę szczególnie narażoną na ekspozycję na sytuację kryzysową związaną z pandemią koronawirusa. Wynika to ze słabiej rozwiniętych u nich mechanizmów przepracowywania takiej sytuacji ${ }^{2}$. Pandemia zmusiła młodych ludzi do rezygnacji z codziennych aktywności i przyczyniła się do utraty poczucia kontroli nad własnym życiem. W konsekwencji doświadczyli oni narastających w nich emocji lęku, szoku, niepewności, złości czy rozczarowania. Dlatego szczególnego znaczenia w tych niecodziennych okolicznościach nabiera udzielanie odpowiedniego wsparcia psychologiczno-pedagogicznego oraz dbanie o relacje. Kwestię tę poruszaja autorzy raportu Thinking about Pedagogy in an Unfolding Pandemic. W ich opinii w planowaniu i podejmowaniu działań przez szkołę i nauczycieli na pierwszy plan powinny wysuwać się zdrowie, bezpieczeństwo i dobre samopoczucie uczniów, a dopiero potem edukacja formalna. Zostało to ujęte w lakonicznie brzmiącym określeniu, Maslow before Bloom ${ }^{3}$.

\footnotetext{
${ }^{1}$ Wiesław Poleszak, Jacek Pyżalski, „Psychologiczna sytuacja dzieci i młodzieży w dobie pandemii”, w Edukacja w czasach pandemii wirusa COVID-19. Z dystansem o tym, co robimy obecnie jako nauczyciele, red. Jacek Pyżalski (Warszawa: EduAkcja, 2020), 7-8.

2 Tomasz Bilicki, „Jak pracować z uczniem w kryzysie w czasie pandemii COVID-19?”, w Edukacja w czasach pandemii wirusa COVID-19, 17.

3 Armand Doucet, Dr. Deborah Netolicky, Koen Timmers, and Francis Jim Tuscano,
} 
Pandemia i jej społeczno-emocjonalne konsekwencje znalazły się w polu zainteresowań pedagogów i psychologów. Naukowcy z ośrodków krajowych i zagranicznych podjęli się badań dotyczących wielu obszarów funkcjonowania edukacji zdalnej. Efektem tego są liczne raporty, które stanowią ważny głos w dyskusji nad edukacją w tym trudnym czasie z perspektywy nauczycieli, rodziców i uczniów. To właśnie te podmioty edukacyjne w bardzo krótkim okresie zostały postawione przed nowymi wyzwaniami, które moga stanowić dla nich zarówno szansę, jak i spore zagrożenie. Ze względu na temat niniejszego opracowania zaprezentowane zostaną po krótce jedynie wyniki badań dotyczących samopoczucia dzieci i młodzieży.

$\mathrm{Z}$ dostępnych raportów wynika, że u większości uczniów nastąpiło pogorszenie samopoczucia $\mathrm{w}$ okresie pandemii. Na o wiele gorsze samopoczucie częściej zwracały uwagę dziewczęta niż chłopcy ${ }^{4}$. Stosunkowo nieliczną grupą są ci młodzi ludzie, którzy odnotowali poprawę zdrowia w sferze psychicznej i fizycznej w porównaniu do czasu sprzed pandemii ${ }^{5}$.

Edukacja zdalna i ograniczone kontakty z rówieśnikami negatywnie wpłynęły na emocje uczniów, powodując smutek, przygnębienie, poczucie osamotnienia, rozbicie psychiczne, a nawet pojawienie się symptomów depresyjnych $^{6}$. Analizując wyniki badań, zaprezentowane w raportach, można również zauważyć, że u niektórych uczniów w czasie edukacji zdalnej pojawiły się

Thinking about Pedagogy in an Unfolding Pandemic. An Independent Report on Approaches to Distance Learning During COVID-19 School Closures, 8-9, accessed May, 20, 2021, https:// issuu.com/educationinternational/docs/2020_research_covid-19_eng.

${ }^{4}$ Zob. Magdalena Bigaj, Maciej Dębski, ,Subiektywny dobrostan i higiena cyfrowa w czasie edukacji zdalnej”, w Edukacja zdalna: co stało się z uczniami, ich rodzicami i nauczyciela$m i$, red. Grzegorz Ptaszek, Grzegorz D. Stunża, Jacek Pyżalski, Maciej Dębski i Magdalena Bigaj (Gdańsk: Gdańskie Wydawnictwo Psychologiczne, 2020), 85; Zob. Katarzyna Makaruk, Joanna Włodarczyk i Renata Szredzińska, „Negatywne doświadczenia młodzieży w trakcie pandemii. Raport z badań ilościowych”, dostęp 24.05.2021, 35, https://fdds.pl/_Resources/ Persis tent/5/0/0/e/500e0774b0109a6892ce777b0d8595f528adea62/Negatywne-doswiadczenia-mlodzie zy-w-trakcie-pandemii.-Raport-z-badan-ilosciowych-1.pdf. Zob. Szymon Grzelak, Dorota Żyro, „Jak wspierać uczniów po roku epidemii? Wyzwania i rekomendacje z obszaru wychowania, profilaktyki i zdrowia psychicznego", dostęp 19.05.2021,18 https://www.ipzin.org/images// pdf/Raport_jak_wspierac_uczniow_po_roku_epidemii.pdf.

${ }^{5}$ Zob. Bigaj, Dębski, ,Subiektywny dobrostan i higiena cyfrowa w czasie edukacji zdalnej”, 83-84; Zob. Makaruk, Włodarczyk i Szredzińska, „Negatywne doświadczenia młodzieży w trakcie pandemii. Raport z badań ilościowych”, 35 .

${ }^{6}$ Zob. Bigaj, Dębski, „Subiektywny dobrostan i higiena cyfrowa w czasie edukacji zdalnej”, 89; Zob. Piotr Długosz, „Blaski i cienie zdalnej edukacji wśród uczniów z obszarów wiejskich", w Wyzwania dla edukacji w sytuacji pandemii COVID-19, red. Norbet G. Pikuła, Katarzyna Jagielska i Joanna M. Łukasik (Kraków: Wydawnictwo Scriptum, 2020), 90. 
różnorodne problemy natury psychosomatycznej, tj. bóle brzucha, bóle głowy, trudności w zasypianiu, zdenerwowanie, przygnębienie, obniżenie nastroju czy brak energii. Badanie stanów psychicznych młodzieży ujawniło spadek motywacji do nauki oraz objawy zmęczenia cyfrowego, objawiającego się przemęczeniem, przeładowaniem informacjami, niechęcią do korzystania z komputera i Internetu, rozdrażnieniem z powodu ciągłego używania technologii informacyjno-komunikacyjnych ${ }^{7}$.

Ponadto z przygotowanych raportów wyraźnie wynika, że większość uczniów doświadczyła w okresie edukacji zdalnej pogorszenia jakości relacji rówieśniczych oraz kontaktów z rodzicami i nauczycielami ${ }^{8}$. Niepokoić może fakt, że dzieci i młodzież o obniżonym samopoczuciu doświadczają zdecydowanie mniej wsparcia ze strony rodziców i nauczycieli niż uczniowie będący w dobrej kondycji psychicznej, przez co zdecydowanie gorzej radzą sobie w kryzysowej sytuacji pandemii ${ }^{9}$.

Przejście szkoły na funkcjonowanie w trybie zdalnym nie uchroniło młodych ludzi przed doświadczaniem krzywdzenia. Doznawanie różnych form przemocy przez niektórych uczniów miało wyraźny wpływ na obniżenie ich samopoczucia. Badana młodzież deklarowała doświadczanie przemocy ze strony osób bliskich, wykorzystania seksualnego z kontaktem fizycznym oraz bycie świadkiem przemocy domowej. Doznawanie przemocy było częściej udziałem dziewcząt niż chłopców, młodzieży w wieku 16-17 lat niż nastolat-

${ }^{7}$ Zob. Bigaj, Dębski, „Subiektywny dobrostan i higiena cyfrowa w czasie edukacji zdalnej”, 95, 98; Zob. Długosz, „Blaski i cienie zdalnej edukacji wśród uczniów z obszarów wiejskich”, 88; Zob. Makaruk, Włodarczyk i Szredzińska, „Negatywne doświadczenia młodzieży w trakcie pandemii. Raport z badań ilościowych”, 35; Zob. Grzelak, Żyro, „Jak wspierać uczniów po roku epidemii? Wyzwania i rekomendacje z obszaru wychowania, profilaktyki i zdrowia psychicznego", 22.

${ }^{8}$ Zob. Jacek Pyżalski „Ważne relacje uczniów i nauczycieli w czasie edukacji zdalnej”, w Edukacja zdalna: co stato sie z uczniami, ich rodzicami i nauczycielami?, 122-123; Zob. Długosz, „Blaski i cienie zdalnej edukacji wśród uczniów z obszarów wiejskich”, 90; Zob. Katarzyna Jagielska „Edukacja zdalna w doświadczeniach uczniów szkół średnich”, w Wyzwania dla edukacji w sytuacji pandemii COVID-19, 111. Zob. Anna Buchner, Maria Wierzbicka, „Edukacja zdalna w czasie pandemii. Raport z badań. Edycja 2”, dostęp: 17.05.2021, 68, https://centrumcyfrowe. pl/edukacja-zdalna/\#Raport; Zob. Grzelak, Żyro, „Jak wspierać uczniów po roku epidemii? Wyzwania i rekomendacje z obszaru wychowania, profilaktyki i zdrowia psychicznego", 19.

${ }^{9}$ Zob. Grzelak, Żyro, „Jak wspierać uczniów po roku epidemii? Wyzwania i rekomendacje w obszaru wychowania, profilaktyki i zdrowia psychicznego", 43. 
ków w wieku 13-15. Niestety młodzież doświadczająca krzywdzenia nie miała w swoim kręgu osoby czy osób, na których wsparcie mogłaby liczyć10 ${ }^{10}$.

Analiza wyników badań, zaprezentowanych w raportach, jednoznacznie pokazała jak wysokie koszty w wymiarze edukacyjnym, społecznym, emocjonalnym i psychologicznym ponieśli uczniowie ${ }^{11}$. Wyraźne obniżenie samopoczucia w wymiarze psychicznym dzieci i młodzieży w czasie izolacji spowodowanej pandemią jest czynnikiem, który sprzyja w krótkiej i dłuższej perspektywie czasowej wzrostowi zachowań ryzykownych i problemowych, tj. cyberprzemoc, uzależnienia behawioralne, uzależnienia od substancji psychoaktywnych $^{12}$.

\section{METODOLOGICZNE ZAŁOŻENIA BADAŃ WŁASNYCH}

Celem przeprowadzonych badań było określenie retrospektywnego (przed pandemią, w systemie pracy szkoły tradycyjnej) i realnego (w czasie trwania pandemii i nauki zdalnej) samopoczucia uczniów w odniesieniu do ich płci, wieku, klasy szkolnej, miejsca zamieszkania i sytuacji materialnej rodziny.

Używając skali pięciostopniowej uczniowie mieli ustosunkować się do następujących twierdzeń: „W mojej szkole w czasie przed pandemią czułem/am się...”; „W e-szkole (edukacji w warunkach domowych spowodowanych pandemią) czuję się...".

Badanie zostało zrealizowane on-line w szkołach podstawowych i ponadpodstawowych z Lublina i podlubelskich miejscowości w 2020 roku. W badaniach udział wzięło 360 uczniów z klas VII (135 osób), VIII (85 osób) szkoły podstawowej oraz klas I szkół ponadpodstawowych (140 osób). W grupie badawczej znalazło się 231 dziewcząt (64\% osób badanych) i 129 chłopców (36\%). Badani uczniowie byli w przedziale wiekowym 12-18 lat, z czego ponad połowa uczniów $(53,1 \%)$ była w wieku 14 i 15 lat (100 i 91 osób). Trzecią pod względem liczebności grupę stanowili szesnastolatkowie - 17,2\% grupy (62 osoby). Niemal 2/3 badanych uczniów (222 osoby; $62 \%$ całości grupy) zamieszkuje w mieście, natomiast mieszkańcami wsi było 138 osób (38\%).

\footnotetext{
${ }^{10}$ Zob. Makaruk, Włodarczyk i Szredzińska, „Negatywne doświadczenia młodzieży w trakcie pandemii. Raport z badań ilościowych”, 12, 52.

11 Zob. Jagielska „Edukacja zdalna w doświadczeniach uczniów szkół średnich”, 103.

12 Zob. Grzelak, Żyro, „Jak wspierać uczniów po roku epidemii? Wyzwania i rekomendacje z obszaru wychowania, profilaktyki i zdrowia psychicznego", 31.
} 
Przedstawione wyniki badań stanowią część projektu badawczego „Szkolne samopoczucie uczniów i nauczycieli w kontekście zadań przyszłościowych" realizowanego pod kierownictwem dr hab. Izabelli M. Łukasik, prof. UMCS.

W celu ustalenia różnic pomiędzy samopoczuciem retrospektywnym a realnym uczniów wykorzystano test t-studenta dla par niezależnych wraz z oceną siły efektu d Cohena. Ponadto skorzystano z następujących metod statystycznych: Chi-kwadrat Pearsona, analiza skupień metodą k-średnich, analiza dyskryminacyjna. Obliczenia dokonane zostały z wykorzystaniem programu statystycznego SPSS 13.3.

\section{WYNIKI BADAŃ WŁASNYCH}

Szkoła obok rodziny jest środowiskiem, które w istotny sposób wpływa na poziom samopoczucia dzieci i młodzieży. Oprócz zdobywania i pogłębiania w niej wiedzy i umiejętności, uczniowie mają również okazję do rozwijania wielu kompetencji społecznych i emocjonalnych oraz budowania relacji ${ }^{13}$. Jak wynika z przeanalizowanych powyżej raportów przejście szkoły w wirtualną rzeczywistość w związku z izolacją społeczną i innymi ograniczeniami wynikającymi z pandemii COVID-19 znacząco pogorszyło samopoczucie psychologiczne, poznawcze, fizyczne i społeczne większości uczniów wpływając na ich jakość życia i dobrostan psychiczny. Potwierdzają to również analizy zawarte w raporcie z badań „Moje s@mopoczucie w e-szkole”, w którym zaprezentowano ilościowe wyniki badania realizowanego w ramach projektu badawczego „Szkolne samopoczucie uczniów i nauczycieli w kontekście zadań przyszłościowych". Na podstawie analizy wyników zawartych w Raporcie można zauważyć, że samopoczucie uczniów w e-szkole różnicują następujące czynniki: sytuacja zdrowotna, warunki do zdalnej edukacji, relacje interpersonalne $z$ rówieśnikami i nauczycielami oraz szanse na samorealizację ${ }^{14}$.

Poniżej zaprezentowano wyniki uzyskane przez badaną młodzież w zakresie retrospektywnego i realnego samopoczucia w oparciu o dwa twierdzenia:

\footnotetext{
${ }^{13}$ Maciej Jakubowski, Krzysztof Konarzewski, Marek Muszyński, Marek Smulczyk i Piotr Walicki, „Szkolne talenty u progu zmian. Polscy uczniowie w najnowszych badaniach międzynarodowych". Raport Fundacji Evidence Institute i Zwiazku Nauczycielstwa Polskiego, dostęp 18.05.2011,88,http://www.evidin.pl/wp-content/uploads/publications/Szkolne-talenty-Europy-uprogu-zmian-raport-EI-ZNP-maj-2017.pdf.

${ }^{14}$ Anna Bieganowska-Skóra, Dorota Pankowska, „Moje s@ mopoczucie w e-szkole. Raport z badań", dostęp 20.05.2021, 70, https://phavi.umcs.pl/at/attachments/2020/1126/112228-mojesamopoczucie-w-e-szkole-raport-z-badan.pdf.
} 
„W mojej szkole w czasie przed pandemią czułem/am się...” oraz „W e-szkole (edukacji w warunkach domowych spowodowanych pandemią) czuję się...".

Tabela 1. Retrospektywne i realne samopoczucie uczniów

\begin{tabular}{|c|c|c|c|c|c|c|}
\hline \multirow{2}{*}{$\begin{array}{c}\text { Samopoczucie przed } \\
\text { pandemia } \\
\text { i w e-szkole }\end{array}$} & \multicolumn{2}{|c|}{$\begin{array}{c}\text { Retrospektywne } \\
\text { samopoczucie }\end{array}$} & $\begin{array}{c}\text { Realne samopoczu- } \\
\text { cie uczniów }\end{array}$ & $\mathrm{t}$ & $\mathrm{p}$ \\
\cline { 2 - 5 } & $\mathrm{M}$ & $\mathrm{SD}$ & $\mathrm{M}$ & $\mathrm{SD}$ & \multirow{2}{*}{5,901} & 0,00 \\
\cline { 2 - 5 } & 4,01 & 0,894 & 3,56 & 1,137 & \\
\hline
\end{tabular}

Otrzymane wyniki pokazują, że badani uczniowie zdecydowanie gorzej czują się w warunkach e-edukacji, niż ucząc się w tradycyjny sposób. Średnia ich wyników w odpowiedzi na pytanie o samopoczucie przed epidemią wyniosła 4,01, a w czasie epidemii 3,56 i różnica ta jest istotna statystycznie $(0,00)$. Siła efektu d Cohena jest umiarkowana i wynosi 0,45.

3.1. Samopoczucie retrospektywne i realne uczniów a ich płeć

W odniesieniu do retrospektywnego i realnego samopoczucia uczniów, otrzymane średnie arytmetyczne skategoryzowano w trzy skupienia, mające na celu dokładniejszą analizę otrzymanych wyników. Na wykresie 1 widać wyraźnie, że skupienia te mają odmienny charakter.

Najliczniejszym ze skupień, jest skupienie nr 2, w skład którego weszło 149 uczniów, deklarujących, że bardzo dobrze, albo dobrze czuli się w szkole przed pandemią, a nieco gorzej określili swoje samopoczucie w e-szkole. W skład tego skupienia weszło 90 dziewcząt, co stanowiło $1 / 4$ wszystkich badanych osób (38,96\% wszystkich dziewcząt). Natomiast chłopców było 59, co stanowiło 16,39\% ogółu badanych i 45,74\% wszystkich chłopców.

Kolejnym co do wielkości jest skupienie nr 1 . W jego skład weszło 125 uczniów, którzy - według ich deklaracji - czuli się raczej dobrze w tradycyjnym systemie kształcenia i źle czują się w e-edukacji. Znalazło się tutaj 47 chłopców (13,06\% ogółu, 36,43\% wszystkich chłopców) i 78 dziewcząt (21,67\% ogółu badanych i $33,77 \%$ wszystkich dziewcząt). 


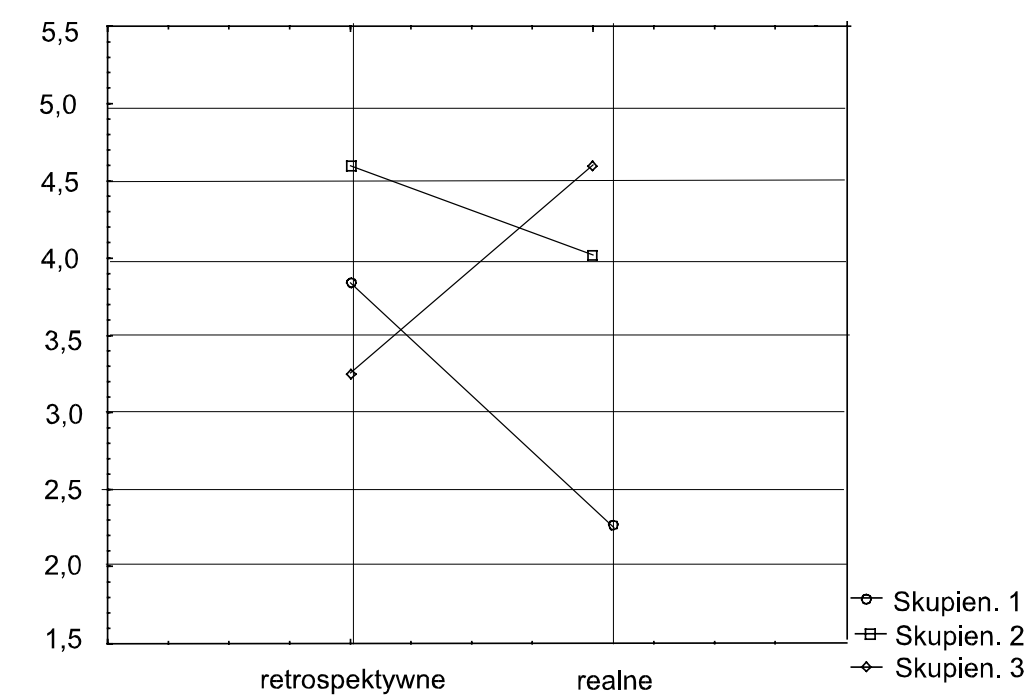

Skupienie 1 - 125 uczniów, skupienie 2 - 149 uczniów, skupienie 3 - 86 uczniów

Wykres 1. Retrospektywne i realne samopoczucie uczniów - skupienia

Skupienie nr 3 okazało się być najmniej licznym (86 osób), ale o zdecydowanie odmiennym od dwóch poprzednich charakterze. Uczniowie zadeklarowali, że w warunkach szkoły tradycyjnej czuli się znacznie gorzej, niż w trakcie nauczania zdalnego. Najczęściej wybieraną odpowiedzią w badaniu samopoczucia retrospektywnego było ,ani dobrze, ani źle”, natomiast samopoczucie w warunkach e-szkoły określali jako bardzo dobre i dobre. Co ciekawe, w skupieniu tym znalazło się więcej uczennic (63; 17,50\% ogółu, 27,27\% wszystkich dziewcząt), niż uczniów (23; 6,39\% ogółu, 17,83\% wszystkich chłopców). Może to łączyć się z faktem, że dziewczęta otrzymują mniejszy poziom wsparcia w szkole niż chłopcy, a także spotykają się z większą ilością hejtu ze strony rówieśników ${ }^{15}$.

Zaskakującym jest fakt, że prawie co czwarty uczeń czuje się lepiej w warunkach edukacji zdalnej i należy się zastanowić nad przyczynami tego stanu rzeczy: jakie potrzeby, a może problemy posiada ta grupa uczniów, która z uwagi na wiek, w jakim się znajduje, powinna posiadać naturalną i silną potrzebę kontaktu z rówieśnikami i przynależności do grupy klasowej. Być może ta grupa uczniów posiada odmienne potrzeby edukacyjne, niż większość rówieśników i w warunkach domowych, gdzie jest mniej dystraktorów, a otaczająca przestrzeń jest

\footnotetext{
15 Bieganowska, Pankowska, „Moje s@mopoczucie w e-szkole. Raport z badań”, 33.
} 
dostosowana do ich wymagań, po prostu czuje się lepiej. Płeć nie była zmienna różnicującą samopoczucie retrospektywne i realne uczniów w poszczególnych skupieniach w sposób istotny statystycznie $\left(\mathrm{p}=0,12 ;\right.$ chi $\left.^{2}=4,17 ; \mathrm{df}=2 ; \mathrm{C}=0,107\right)$.

\subsection{Samopoczucie retrospektywne i realne uczniów a ich wiek}

Istotne statystycznie różnice w percepcji retrospektywnego i realnego samopoczucia zaszły pomiędzy badanymi osobami biorąc pod uwagę ich wiek $\left(\mathrm{p}=0,01 ; \mathrm{chi}^{2}=19,61 ; \mathrm{df}=8 ; \mathrm{C}=0,227\right)$.

Tabela 2. Retrospektywne i realne samopoczucie uczniów a ich płeć

\begin{tabular}{|l|c|c|c|c|}
\hline \multicolumn{1}{|c|}{ Płeć } & Skupienie 3 & Skupienie 1 & Skupienie 2 & Razem \\
\hline dziewczęta & 63 & 78 & 90 & 231 \\
\hline$\%$ kolumny & $73,26 \%$ & $62,40 \%$ & $60,40 \%$ & \\
\hline$\%$ wiersza & $27,27 \%$ & $33,77 \%$ & $38,96 \%$ & \\
\hline$\%$ ogółu & $17,50 \%$ & $21,67 \%$ & $25,00 \%$ & $64,17 \%$ \\
\hline chłopcy & 23 & 47 & 59 & 129 \\
\hline$\%$ kolumny & $26,74 \%$ & $37,60 \%$ & $39,60 \%$ & \\
\hline$\%$ wiersza & $17,83 \%$ & $36,43 \%$ & $45,74 \%$ & \\
\hline$\%$ ogółu & $6,39 \%$ & $13,06 \%$ & $16,39 \%$ & $35,83 \%$ \\
\hline Ogółem & 86 & 125 & 149 & 360 \\
\hline$\%$ ogółu & $23,89 \%$ & $34,72 \%$ & $41,39 \%$ & $100,00 \%$ \\
\hline
\end{tabular}

W skład najliczniejszego skupienia 2, czyli uczniów, którzy wykazali najwyższy poziom samopoczucia retrospektywnego i realnego, weszło najwięcej uczniów w wieku 14 lat (47 osób, stanowiących 31,54\% wszystkich z tego skupienia i 47\% ogółu 14-latków), 15 lat (30 osób, 20,13\% badanych ze skupienia 2 i 32,97\% wszystkich 15-latków), a także uczniów poniżej 14 roku życia (41 osób, $27,52 \%$ uczniów z tego skupienia i 58,57\% wszystkich badanych poniżej 14 lat). W tej grupie znalazło się najmniej uczniów powyżej 16 roku życia (10 osób, 6,71\% skupienia), a także 16-latków (21, 14,09\% skupienia i 33,87\% wszystkich 16-latków). Natomiast w skupieniu 1, w którym to uczniowie najboleśniej odczuli skutki nauczania zdalnego, znalazł się prawie co trzeci piętnastolatek $(31,20 \%)$ i było to skupienie, w którym znalazło się ich najwięcej (43,55\%). Mniej, bo 29 osób (23,20\% całego skupienia) znalazło się tutaj 14-latków i 16-latków (27 osób, stanowiących 21,60\% skupienia). Najmniej było tu 
nastego i powyżej szesnastego roku życia (po 15 osób, co stanowiło $12 \%$ skupienia). Czternastolatkowie i piętnastolatkowie stanowią ponad połowę skupienia 3 (odpowiednio: 27,91\% i 25,58\%), a 16-latków i uczniów poniżej 14 roku życia było w tej grupie dokładnie tyle samo, bo 14 osób (16,28\% całego skupienia). Najmniej znalazło się tutaj osób powyżej 16 roku życia (12 osób, 13,95\% całego skupienia). Analizując rozkład procentowy uczniów ze względu na wiek w poszczególnych skupieniach, należy zauważyć, że najmłodsi uczniowie, tj. w wieku 14 lat i poniżej, najczęściej deklarowali, że bardzo dobrze czuli się w warunkach szkoły tradycyjnej. Natomiast uczniowie od 15 roku życia i starsi najczęściej stwierdzali, że w kształceniu zdalnym ich samopoczucie uległo znacznemu pogorszeniu (42,86\% 15-latków, 43,55\% 16-latków i 40,54\% uczniów powyżej 16 roku życia) (tabela 3).

Tabela 3. Retrospektywne i realne samopoczucie uczniów a ich wiek

\begin{tabular}{|l|c|c|c|c|}
\hline Wiek & Skupienie 3 & Skupienie 1 & Skupienie 2 & Razem \\
\hline $\mathbf{1 4}$ lat & 24 & 29 & 47 & 100 \\
\hline$\%$ kolumny & $27,91 \%$ & $23,20 \%$ & $31,54 \%$ & \\
\hline$\%$ wiersza & $24,00 \%$ & $29,00 \%$ & $47,00 \%$ & \\
\hline$\%$ ogółu & $6,67 \%$ & $8,06 \%$ & $13,06 \%$ & $27,78 \%$ \\
\hline 15 lat & 22 & 39 & 30 & 91 \\
\hline$\%$ kolumny & $25,58 \%$ & $31,20 \%$ & $20,13 \%$ & \\
\hline$\%$ wiersza & $24,18 \%$ & $42,86 \%$ & $32,97 \%$ & \\
\hline$\%$ ogółu & $6,11 \%$ & $10,83 \%$ & $8,33 \%$ & $25,28 \%$ \\
\hline $\mathbf{1 6}$ lat & 14 & 27 & 21 & 62 \\
\hline$\%$ kolumny & $16,28 \%$ & $21,60 \%$ & $14,09 \%$ & \\
\hline$\%$ wiersza & $22,58 \%$ & $43,55 \%$ & $33,87 \%$ & \\
\hline$\%$ ogółu & $3,89 \%$ & $7,50 \%$ & $5,83 \%$ & $17,22 \%$ \\
\hline$<\mathbf{1 4}$ lat & 14 & 15 & 41 & 70 \\
\hline$\%$ kolumny & $16,28 \%$ & $12,00 \%$ & $27,52 \%$ & \\
\hline$\%$ wiersza & $20,00 \%$ & $21,43 \%$ & $58,57 \%$ & \\
\hline$\%$ ogółu & $3,89 \%$ & $4,17 \%$ & $11,39 \%$ & $19,44 \%$ \\
\hline$>\mathbf{1 6}$ lat & 12 & 15 & 10 & 37 \\
\hline$\%$ kolumny & $13,95 \%$ & $12,00 \%$ & $6,71 \%$ & \\
\hline$\%$ wiersza & $32,43 \%$ & $40,54 \%$ & $27,03 \%$ & \\
\hline$\%$ ogółu & $3,33 \%$ & $4,17 \%$ & $2,78 \%$ & $10,28 \%$ \\
\hline Ogółem & 86 & 125 & 149 & 360 \\
\hline
\end{tabular}


Najmłodsi uczniowie, będąc najczęściej w VII klasie, nie odczuli tak boleśnie jak pozostali „efektów ubocznych” pandemii, w postaci chociażby izolacji od rówieśników. W przypadku uczniów klas VIII znaczące pogorszenie samopoczucia wynikać może nie tylko z drastycznego oddzielenia od grupy rówieśniczej, ale i ze świadomości przystępowania przez nich do egzaminu ósmoklasisty. Z kolei u uczniów starszych, tj. z klas I szkół ponadpodstawowych samopoczucie realne $w$ momencie badania, czyli w warunkach edukacji zdalnej było znacznie gorsze, niż w okresie przed pandemią. Młodzież z klas I szkół ponadpodstawowych, rozpoczynając naukę w nowej szkole, nie zdążyła się jeszcze zintegrować z grupą rówieśniczą. Uczestnictwo zdalne w zajęciach, pokazywanie się na kamerce dla młodzieży w tym wieku, która nie miała wielu okazji, aby się poznać osobiście, może być doświadczeniem stresującym. Dodatkowo dochodzi fakt braku zajęć wychowawczych on-line, a także podejmowania działań ze strony szkoły mających na celu integrację zespołu klasowego. Pamiętać należy także o znacznym zwiększeniu wymagań wobec uczniów w szkołach ponadpodstawowych, w tym ilości treści programowych przeznaczonych do opanowania, a także stresie związanym ze sposobami weryfikacji wiedzy w formie online.

\subsection{Samopoczucie retrospektywne i realne uczniów}

\section{a klasa szkolna}

Otrzymane w wyniku analizy wnioski dotyczące samopoczucia retrospektywnego i realnego, biorąc pod uwagę wiek osób badanych, znalazły swoje potwierdzenie podczas analizy danych pod kątem przynależności do poszczególnych klas. Różnice osiągnięte pomiędzy wynikami uczniów z poszczególnych klas okazały się być istotne statystycznie $\left(\mathrm{p}=0,00 ; \mathrm{chi}^{2}=17,32 ; \mathrm{df}=4\right.$; $\mathrm{C}=0,214$ ). Ponad połowa uczniów z klas VII szkoły podstawowej $(53,33 \%$ wszystkich uczniów klas VII) weszła w skład skupienia drugiego, co oznacza, że ich poziom samopoczucia w e-szkole nieznacznie się obniżył. Reszta uczniów z tej grupy podzieliła się pomiędzy dwoma skupieniami niemal po równo, tj. 23,70\% - skupienie 1 i 22,96\% skupienie 3. Jeśli chodzi o uczniów klas VIII, to mniej więcej równy ich procent wszedł w obręb skupienia uczniów odczuwających znaczny spadek samopoczucia (skupienie $1-35,29 \%$ wszystkich ósmoklasistów) i skupienia 2, tj. uczniów, którzy określili, że ich samopoczucie nieznacznie się obniżyło podczas lekcji zdalnych $(38,82 \%$ wszystkich uczniów z klas VIII). Pozostałe 25,88\% ósmoklasistów znalazło się w skupieniu 3, co oznacza, że wyżej ocenili oni swoje samopoczucie w eszkole, niż przed pandemią. Najbardziej niezadowoleni z zaistniałej sytuacji są uczniowie klas I szkół ponadpodstawowych. Prawie co drugi uczeń z tej 
grupy (45\% wszystkich pierwszoklasistów) odczuł znaczne pogorszenie swojego samopoczucia. Uczniowie ci stanowią połowę skupienia 1. Co czwarty uczeń z klas I szkoły ponadpodstawowej określił swoje samopoczucie w nauczaniu zdalnym jako lepsze, niż w szkole pracującej w systemie tradycyjnym (skupienie 3), a 31 (43\%) uczniów, czuje się trochę gorzej w systemie pracy zdalnej i znaleźli się oni w skupieniu 2 (tabela 4).

Skład skupienia 3 (uczniów o lepszym samopoczuciu realnym niż retrospektywnym) nie jest łatwy do interpretacji, okazuje się, że podobnie jak w przypadku zmiennej wieku, tak i tutaj otrzymane dane nie prowadzą do wyraźnych wniosków. W skład tego skupienia weszło 38,37 \% uczniów klas I szkół ponadpodstawowych, 36,05\% siódmoklasistów i 25,58\% ósmoklasistów. Otrzymane wyniki skłaniają do podjęcia analizy w kierunku zróżnicowania tej grupy pod kątem potrzeb edukacyjnych uczniów, wynikających $\mathrm{z}$ ich specyfiki funkcjonowania.

Tabela 4. Retrospektywne i realne samopoczucie uczniów a klasa szkolna

\begin{tabular}{|l|c|c|c|c|}
\hline Klasa & Skupienie 3 & Skupienie 1 & Skupienie 2 & Razem \\
\hline $\begin{array}{l}\text { I (szkoła ponad- } \\
\text { podstawowa) }\end{array}$ & 33 & 63 & 44 & 140 \\
\hline$\%$ kolumny & $38,37 \%$ & $50,40 \%$ & $29,53 \%$ & \\
\hline$\%$ wiersza & $23,57 \%$ & $45,00 \%$ & $31,43 \%$ & \\
\hline$\%$ ogółu & $9,17 \%$ & $17,50 \%$ & $12,22 \%$ & $38,89 \%$ \\
\hline VIII & 22 & 30 & 33 & 85 \\
\hline$\%$ kolumny & $25,58 \%$ & $24,00 \%$ & $22,15 \%$ & \\
\hline$\%$ wiersza & $25,88 \%$ & $35,29 \%$ & $38,82 \%$ & \\
\hline$\%$ ogółu & $6,11 \%$ & $8,33 \%$ & $9,17 \%$ & $23,61 \%$ \\
\hline VII & 31 & 32 & 72 & 135 \\
\hline$\%$ kolumny & $36,05 \%$ & $25,60 \%$ & $48,32 \%$ & \\
\hline$\%$ wiersza & $22,96 \%$ & $23,70 \%$ & $53,33 \%$ & \\
\hline$\%$ ogółu & $8,61 \%$ & $8,89 \%$ & $20,00 \%$ & $37,50 \%$ \\
\hline Ogółem & 86 & 125 & 149 & 360 \\
\hline$\%$ ogółu & $23,89 \%$ & $34,72 \%$ & $41,39 \%$ & $100,00 \%$ \\
\hline
\end{tabular}




\subsection{Samopoczucie retrospektywne i realne uczniów}

a ich miejsce zamieszkania

Nie wystąpiły różnice statystyczne, jeśli chodzi o odczuwany poziom samopoczucia retrospektywnego i realnego w zakresie zmiennej: miejsce zamieszkania ( $\mathrm{p}=0,59 \mathrm{chi}^{2}=1,03 ; \mathrm{df}=2 ; \mathrm{C}=0,053$ ). Ponad $60 \%$ uczniów zamieszkiwało na terenach miejskich, zaś niecałe $40 \%$ - wiejskich. Największa liczba badanych uczniów (93 osoby, co stanowiło 25,83\% wszystkich respondentów) weszła w skład skupienia 2 i są to uczniowie zamieszkujący w mieście (tabela 5). Uczniowie $\mathrm{z}$ terenów wiejskich $\mathrm{w}$ tym skupieniu stanowili 15,56\% wszystkich badanych (56 osób). W skład skupienia 1 (uczniów odczuwających znaczne pogorszenie samopoczucia w warunkach e-edukacji) weszły 52 osoby z terenów wiejskich (14,44\% wszystkich badanych) i 73 osoby z terenów miejskich $(20,28 \%$ ogółu). Natomiast w skupieniu 3 znalazło się 30 uczniów mieszkających na wsi $(8,33 \%$ ogółu) i 56 uczniów z miasta (15,56\% ogółu). Okazuje się, że miejsce zamieszkania nie miało istotnego wpływu na zmianę odczuwanego samopoczucia.

Tabela 5. Retrospektywne i realne samopoczucie uczniów a ich miejsce zamieszkania

\begin{tabular}{|l|c|c|c|c|}
\hline $\begin{array}{c}\text { Miejsce } \\
\text { zamieszkania }\end{array}$ & Skupienie 3 & Skupienie 1 & Skupienie 2 & Razem \\
\hline wieś & 30 & 52 & 56 & 138 \\
\hline$\%$ kolumny & $34,88 \%$ & $41,60 \%$ & $37,58 \%$ & \\
\hline$\%$ wiersza & $21,74 \%$ & $37,68 \%$ & $40,58 \%$ & \\
\hline$\%$ ogółu & $8,33 \%$ & $14,44 \%$ & $15,56 \%$ & $38,33 \%$ \\
\hline miasto & 56 & 73 & 93 & 222 \\
\hline$\%$ kolumny & $65,12 \%$ & $58,40 \%$ & $62,42 \%$ & \\
\hline$\%$ wiersza & $25,23 \%$ & $32,88 \%$ & $41,89 \%$ & \\
\hline$\%$ ogółu & $15,56 \%$ & $20,28 \%$ & $25,83 \%$ & $61,67 \%$ \\
\hline Ogółem & 86 & 125 & 149 & 360 \\
\hline$\%$ ogółu & $23,89 \%$ & $34,72 \%$ & $41,39 \%$ & $100,00 \%$ \\
\hline
\end{tabular}

3.5. Samopoczucie retrospektywne i realne uczniów a sytuacja materialna rodziny

Ostatnia analizowana zmienna w sposób istotny statystycznie determinowała samopoczucie badanych uczniów ( $\left.\mathrm{p}=0,01 ; \mathrm{chi}^{2}=16,66 ; \mathrm{df}=6 ; \mathrm{C}=0,204\right)$. 
Okazuje się, że najlepiej swoją sytuację materialną określili uczniowie, którzy byli zadowoleni z przejścia $\mathrm{w}$ tryb nauki zdalnej (skupienie 3, tabela 6). Jako bardzo dobrą określiło ją 21 uczniów (24,42\% tego skupienia), jako dobrą 60 osób (69,77\% skupienia). Tylko 5 osób stwierdziło, że ich sytuacja materialna jest ,ani dobra, ani zła” (5,81\% skupienia). Nikt z badanych nie uznał, że jest ona zła. Młodzież, która była mniej zadowolona z warunków e-edukacji, niż z systemu szkoły tradycyjnej (skupienie 2), w zdecydowanej większości dobrze określiła swoją sytuację materialną (dobra: 96 osób, 64,43\% skupienia; bardzo dobra: 34 osoby, 22,82\% skupienia).

Tabela 6. Retrospektywne i realne samopoczucie uczniów a ich sytuacja materialna

\begin{tabular}{|l|c|c|c|c|}
\hline \multicolumn{1}{|c|}{$\begin{array}{c}\text { Sytuacja } \\
\text { materialna }\end{array}$} & Skupienie 3 & Skupienie 1 & Skupienie 2 & Razem \\
\hline bardzo dobra & 21 & 24 & 34 & 79 \\
\hline$\%$ kolumny & $24,42 \%$ & $19,20 \%$ & $22,82 \%$ & \\
\hline$\%$ wiersza & $26,58 \%$ & $30,38 \%$ & $43,04 \%$ & \\
\hline$\%$ ogółu & $5,83 \%$ & $6,67 \%$ & $9,44 \%$ & $21,94 \%$ \\
\hline dobra & 60 & 70 & 96 & 226 \\
\hline$\%$ kolumny & $69,77 \%$ & $56,00 \%$ & $64,43 \%$ & \\
\hline$\%$ wiersza & $26,55 \%$ & $30,97 \%$ & $42,48 \%$ & \\
\hline$\%$ ogółu & $16,67 \%$ & $19,44 \%$ & $26,67 \%$ & $62,78 \%$ \\
\hline ani dobra, ani zła & 5 & 29 & 18 & 52 \\
\hline$\%$ kolumny & $5,81 \%$ & $23,20 \%$ & $12,08 \%$ & \\
\hline$\%$ wiersza & $9,62 \%$ & $55,77 \%$ & $34,62 \%$ & \\
\hline$\%$ ogółu & $1,39 \%$ & $8,06 \%$ & $5,00 \%$ & $14,44 \%$ \\
\hline zła & 0 & 2 & 1 & 3 \\
\hline$\%$ kolumny & $0,00 \%$ & $1,60 \%$ & $0,67 \%$ & \\
\hline$\%$ wiersza & $0,00 \%$ & $66,67 \%$ & $33,33 \%$ & \\
\hline$\%$ ogółu & $0,00 \%$ & $0,56 \%$ & $0,28 \%$ & $0,83 \%$ \\
\hline Ogółem & 86 & 125 & 149 & 360 \\
\hline$\%$ ogółu & $23,89 \%$ & $34,72 \%$ & $41,39 \%$ & $100,00 \%$ \\
\hline
\end{tabular}

Tylko jedna osoba stwierdziła, że jest ona zła (0,67\% całego skupienia), a 18 uczniów uznało, że nie jest ona ani dobra, ani zła (12,08\% skupienia). Zdecydowaną różnicę w postrzeganiu swojej sytuacji materialnej dostrzeżono pośród 
osób badanych ze skupienia 1 . Nieco ponad połowa wszystkich uczniów z tej grupy (56\%, 70 osób) określiła ją jako dobrą, a 19,20\% jako bardzo dobrą. Ze wszystkich trzech analizowanych grup, w skupieniu 1, znalazła się największa liczba uczniów, którzy uznali swoją sytuację materialną jako „ani dobrą ani złą" (29 osób, co stanowi 23,30\% skupienia). Dwie osoby określiło ją jako złą. Uzyskane wyniki badań w tym zakresie pokazują, że ocena edukacji na odległość zależy prawdopodobnie od posiadania odpowiednich warunków do uczenia się w e-szkole. Uczniowie, którzy lepiej ocenili swoją sytuację materialną, są także bardziej zadowoleni z uczenia się na odległość. Być może dysponują oni lepszymi możliwościami technicznymi (sprzęt, dobre łącze internetowe, oprogramowanie zarządzające zdalną edukacją), lepszymi warunkami lokalowymi, nie są narażeni na „odgłosy domu” i mogą swobodnie i aktywnie uczestniczyć w prowadzonych zajęciach. Z drugiej strony, uczniowie, którzy są zniechęceni i zdecydowanie gorzej ocenili swoje samopoczucie realne w kształceniu zdalnym, mogą postrzegać swoją sytuację materialną jako gorszą i analogicznie, uczniowie, których poziom samopoczucia realnego jest lepszy, mogą lepiej ją oceniać.

$\mathrm{W}$ podsumowaniu powyższych analiz skorzystano z wyników równania dyskryminacyjnego. Jest ono pomocne przy ustaleniu, które zmienne są najlepszymi predyktorami samopoczucia badanej młodzieży.

Tabela 7. Zmienne niezależne - równanie dyskryminacyjne

\begin{tabular}{|l|c|c|c|c|c|c|}
\hline \multicolumn{1}{|c|}{$\mathrm{N}=360$} & $\begin{array}{c}\text { Lambda } \\
\text { Wilksa }\end{array}$ & $\begin{array}{c}\text { Czastk. } \\
\text { Wilksa }\end{array}$ & $\begin{array}{c}\mathrm{F} \text { usun. } \\
(2,355)\end{array}$ & $\mathrm{p}$ & Toler. & $\begin{array}{c}\text { 1-Toler. } \\
(\mathrm{R}-\mathrm{kwad})\end{array}$ \\
\hline klasa & 0,96 & 0,95 & 8,77 & 0,00 & 0,99 & 0,00 \\
\hline $\begin{array}{l}\text { sytuacja } \\
\text { materialna }\end{array}$ & 0,94 & 0,97 & 4,50 & 0,01 & 0,99 & 0,00 \\
\hline płeć & 0,92 & 0,98 & 1,81 & 0,16 & 0,99 & 0,00 \\
\hline
\end{tabular}

Do skonstruowanego modelu zmiennych zależnych i niezależnych spośród pięciu zmiennych demograficzno-społecznych, tj. płeć, wiek, klasa, miejsce zamieszkania i sytuacja materialna weszły tylko dwie. Zmiennymi, które wyjaśniają obecność największych różnic w poziomie samopoczucia uczniów, okazały się być: klasa, do której uczęszczają badani oraz ich sytuacja materialna. Analizując wyniki badań przyjąć zatem należy, że sytuacja młodych osób w czasie pandemii nie jest jednorodna. Uczniom uczęszczającym do I klas szkoły ponadpodstawowej istotnie bardziej obniżył się poziom samo- 
poczucia niż uczniom z klas VII i VIII szkoły podstawowej. Może się to wiązać $\mathrm{z}$ rozpoczęciem przez nich nauki w nowym typie szkoły, w nowej grupie rówieśniczej i z nowymi nauczycielami. Pandemia koronawirusa i wynikające $\mathrm{z}$ niej ograniczenia, w tym izolacja społeczna i edukacja prowadzona w trybie zdalnym, dodatkowo skomplikowały tę sytuację, czyniąc ją psychologicznie trudną ze względu na brak możliwości bezpośrednich kontaktów. Młodzież, u której nastąpiło pogorszenie samopoczucia w trakcie trwania edukacji zdanej, istotnie częściej skarżyła się także na swoją sytuację materialną. Ma to związek z tym, że uczęszczanie do e-szkoły wymaga odpowiedniego zaplecza technicznego w postaci sprzętu oraz łącza internetowego. Gorsza sytuacja materialna rodziny może prowadzić u niektórych uczniów do pojawienia się zakłóceń a nawet do wykluczenia ich z codziennej pracy szkolnej.

\section{IMPLIKACJE PRAKTYCZNE}

Trwająca od ponad roku epidemia koronawirusa i związana z nią izolacja społeczna doprowadziła do pogorszenia samopoczucia uczniów. Zdecydowana większość z nich gorzej czuje się w warunkach edukacji zdalnej, niż w systemie szkoły tradycyjnej.

Przeprowadzone analizy pozwoliły na wyodrębnienie trzech grup młodzieży o różnym profilu samopoczucia:

- młodzieży, której samopoczucie znacząco pogorszyło się w okresie pandemii i w trakcie kształcenia zdalnego,

- młodzieży, która odczuła nieznaczny spadek samopoczucia w związku z pandemią i przejściem na zdalny tryb kształcenia,

- młodzieży, która lepiej czuje się w warunkach e-edukacji.

Każda $\mathrm{z}$ tych grup po powrocie do nauczania w systemie tradycyjnym będzie wymagała indywidualnego podejścia, uwzględniającego ich kondycję psychiczną, potrzeby i oczekiwania.

Okazało się, że zmiennymi różnicującymi w sposób istotny samopoczucie uczniów są: wiek, klasa i sytuacja materialna. Płeć i miejsce zamieszkania nie mają tak znaczącego wpływu na to, jak uczniowie odczuli zmianę swojego samopoczucia.

Na podstawie wniosków, wynikających z analizy danych, należy zwrócić uwagę na działania, jakie należy podjąć w związku z negatywnymi konsekwencjami pandemii koronawirusa:

1. Z uwagi na znaczące obniżenie samopoczucia w okresie pandemii uczniowie, powracający do szkół powinni zostać objęci wsparciem psychologicz- 
no-pedagogicznym, a także działaniami wychowawczymi mającymi na celu intensywną integrację zespołów klasowych. Potrzeba integracji grup jest szczególnie ważna w przypadku uczniów z klas I szkół ponadpodstawowych.

2. Pogorszenie samopoczucia uczniów w tym okresie wymaga natychmiastowych działań pedagogiczno-psychologicznych, koncentrujących się na wsparciu ucznia jako jednostki, a także jako części zespołu klasowego. Działania szkół powinny być skierowane również do rodziców uczniów, do których należy wyjść z działaniami informacyjno-szkoleniowymi, prowadzonymi najlepiej w formie warsztatów. Nie jest to możliwe bez zwiększonego wsparcia pedagogów i psychologów w szkołach (niestety wiele placówek nie posiada psychologów szkolnych).

3. Wszyscy nauczyciele, a nie tylko wychowawcy klas, powinni być gruntownie przeszkoleni $\mathrm{z}$ zakresu wsparcia dzieci i młodzieży z problemami emocjonalnymi i psychicznymi, a także posiadać podstawy wiedzy z zakresu udzielania im wsparcia. Należy stworzyć i wdrażać programy profilaktyczne, mające na celu budowanie psychicznej odporności dzieci i młodzieży poprzez naukę m.in. identyfikowania emocji, radzenia sobie z nimi i działania w sytuacji stresowej czy kryzysowej; wyposażenia ich w narzędzia niezbędne do efektywnego komunikowania się z otoczeniem i wzmacniania poczucia własnej wartości. Zaistniała sytuacja epidemii koronawirusa pokazała, że czas najwyższy, aby zapisy w programach profilaktyczno-wychowawczych szkół znalazły realne odbicie w ich działaniach. Wyposażenie uczniów przez szkołę w umiejętności miękkie będzie sprzyjało zachowaniu przez nich dobrostanu, w tym zdrowia psychicznego i powinno zmniejszać liczbę uczniów doświadczających poważnych kryzysów w tym zakresie.

4. Biorąc pod uwagę fakt, że istnieje grupa uczniów, której samopoczucie zdecydowanie poprawiło się w warunkach edukacji zdalnej, należy pochylić się nad przyczynami tego stanu rzeczy i zastanowić się nad potrzebami, problemami tych uczniów, a także dostosowaniem metod, form i środków pracy do ich potrzeb.

5. Ponieważ zmienną warunkującą w sposób istotny samopoczucie uczniów była sytuacja materialna, należy zastanowić się nad innymi formami kształcenia zdalnego dla uczniów, którzy nie mieli spełnionych odpowiednich warunków w tym zakresie (np. małe grupy uczniów zorganizowane w szkołach).

6. Nauka klas VIII powinna być chociaż częściowo zorganizowana w sposób tradycyjny, ponieważ uczniowie ci zmagali się nie tylko ze stresem związanym z pandemią i izolacją społeczną, ale także ze stresem związanym z egzaminem ósmoklasistów. Jest to pierwszy poważny egzamin w życiu uczniów, dlatego wskazane jest objęcie ich szczególną uwagą przez nauczycieli, pedagogów i psy- 
chologów szkolnych. Niedopuszczalną praktyką w ich przypadku jest rezygnacja z realizacji godzin wychowawczych, w celu powtórki materiału do egzaminów, co jak pokazały dostępne raporty okazało się być niestety częstą praktyką w szkołach nie tylko podstawowych, ale i średnich ${ }^{16}$.

7. Doświadczenia wyniesione z edukacji zdalnej spowodowanej zamknięciem szkół w wyniku pandemii wywołanej wirusem SARS-CoV-2, który powoduje chorobę COVID-19, powinny być właściwie wykorzystane przez wszystkie instytucje edukacyjne i podmioty odpowiedzialne za ten proces. Najważniejsze kwestie powinny sprowadzać się do wypracowania na przyszłość możliwie najlepszych standardów w planowaniu i przebiegu edukacji w sposób zdalny i hybrydowy, aby zagwarantować uczniom jak najlepsze warunki do samorozwoju, budowania relacji i rozumienia świata, a dopiero potem do realizacji podstawy programowej i weryfikacji wiedzy ${ }^{17}$. Dlatego należy szkolić nauczycieli w zakresie efektywnych form kształcenia zdalnego i hybrydowego, także w zakresie wspierania swoich uczniów i integrowania zespołów klasowych w warunkach online. Otrzymane wyniki badań są spójne z doniesieniami z badań innych autorów dotyczących sytuacji uczniów w czasie trwania pandemii. Warto zauważyć, że pogorszenie samopoczucia dotyczy także nauczycieli i rodziców uczniów ${ }^{18}$. Miniony rok pokazał jak dynamicznie dokonują się zmiany sytuacji w Polsce i na świecie związanej z nieprzewidywalnością wirusa SARS-CoV-2 i pojawianiem się coraz to nowych jego mutacji. W związku z tym postawienie zdecydowanych wniosków praktycznych $\mathrm{w}$ tym zakresie jest wyjątkowo trudne. Nie jesteśmy w stanie stwierdzić, czy szkoły powróca do tradycyjnego systemu pracy, czy co jakiś czas będą zmuszone pracować w systemie hybrydowym bądź zdalnym. Jedno jest pewne, szkolnictwo musi nauczyć się szybko dostosowywać do zmian, a przede wszystkim zadbać o ochronę zdrowia uczniów w wymiarze psychicznym i fizycznym, co stanowi podstawę dobrego funkcjonowania dzieci i młodzieży oraz wykorzystywać wszystkie dostępne formy wsparcia umożliwiające rozwój osobisty i społeczny uczniów.

\footnotetext{
16 Zob. Grzelak, Żyro, „Jak wspierać uczniów po roku epidemii? Wyzwania i rekomendacje z obszaru wychowania, profilaktyki i zdrowia psychicznego", 63-69.

${ }^{17}$ Grzegorz Ptaszek, „Słowo wstępne”, w Edukacja zdalna: co stało się z uczniami, ich rodzicami i nauczycielami?, 6.

${ }^{18}$ Zob. Joanna M. Łukasik, Katarzyna Jagielska, Anna Mróz i Paulina Koperna, „Młodzi nauczyciele o zdalnej edukacji w czasie COVID-19”, 49; Buchner, Wierzbicka, „Edukacja zdalna w czasie pandemii. Raport z badań. Edycja 2”; Bigaj, Dębski, „Subiektywny dobrostan i higiena cyfrowa w czasie edukacji zdalnej”, 83-85; Grzelak, Żyro, „Jak wspierać uczniów po roku epidemii? Wyzwania i rekomendacje w obszaru wychowania, profilaktyki i zdrowia psychicznego", 29, 50.
} 
BIBLIOGRAFIA

Bieganowska-Skóra, Anna, Dorota Pankowska. „Moje s@mopoczucie w e-szkole. Raport z badań”.Dostęp20.05.2021.https://phavi.umcs.pl/at/attachments/2020/1126/112228-moje-samopoczucie-w-e-szkole-raport-z-badan.pdf.

Bigaj, Magdalena, Maciej Dębski. „Subiektywny dobrostan i higiena cyfrowa w czasie edukacji zdalnej”. W Edukacja zdalna: co stało się z uczniami ich rodzicami i nauczycielami?, red. Grzegorz Ptaszek, Grzegorz D. Stunża, Jacek Pyżalski, Maciej Dębski, Magdalena Bigaj, 75-111. Gdańsk: Gdańskie Wydawnictwo Psychologiczne, 2020.

Bilicki, Tomasz. „Jak pracować z uczniem w kryzysie w czasie pandemii COVID-19?” W Edukacja $w$ czasach pandemii wirusa COVID-19. Z dystansem o tym, co robimy obecnie jako nauczyciele, red. Jacek Pyżalski, 16-19. Warszawa: EduAkcja, 2020.

Buchner, Anna, Maria Wierzbicka. „Edukacja zdalna w czasie pandemii. Raport z badań. Edycja 2", Centrum Cyfrowe. Dostęp: 17.05.2021. https://centrumcyfrowe.pl/edukacja-zdalna/\#Raport.

Długosz, Piotr. „Blaski i cienie zdalnej edukacji wśród uczniów z obszarów wiejskich”. W Wyzwania dla edukacji w sytuacji pandemii COVID-19, red. Norbert G. Pikuła, Katarzyna Jagielska, Joanna M. Łukasik, 71-94. Kraków: Wydawnictwo Scriptum, 2020.

Doucet, Armand, Dr. Deborah Netolicky, Koen Timmers, Francis Jim Tuscano. „Thinking about Pedagogy in an Unfolding Pandemic”. Accessed: May 20, 2021, https://issuu.com/e ducationin ternational/docs/2020_research_covid-19_eng.

Grzelak, Szymon, Dorota Żyro. „Jak wspierać uczniów po roku epidemii? Wyzwania i rekomendacje z obszaru wychowania, profilaktyki i zdrowia psychicznego”. Dostęp: 19.05.2021. https:// www.ipzin.org/images//pdf/Raport_jak_wspierac_uczniow_po_roku_epidemii.pdf.

Jagielska, Katarzyna. „Edukacja zdalna w sytuacji pandemii w doświadczeniach uczniów szkół średnich". W Wyzwania dla edukacji w sytuacji pandemii COVID-19, red. Norbert G. Pikuła, Katarzyna Jagielska, Joanna M. Łukasik, 95-117. Kraków: Wydawnictwo Scriptum, 2020.

Jakubowski, Maciej, Krzysztof Konarzewski, Marek Muszyński, Marek Smulczyk, Piotr Walicki. „Szkolne talenty u progu zmian. Polscy uczniowie w najnowszych badaniach międzynarodowych". Raport Fundacji Evidence Institute i Zwiazku Nauczycielstwa Polskiego. Dostęp 18.05. 2011. http://www.evidin.pl/wp-content/uploads/publications/Szkolne-talentyEuropy-u-progu-zm ian-raport-EI-ZNP-maj-2017.pdf.

Łukasik, Joanna M., Katarzyna Jagielska, Anna Mróz, Paulina Koperna. „Młodzi nauczyciele o zdalnej edukacji w czasie COVID-19". W Wyzwania dla edukacji w sytuacji pandemii COVID-19, red. Norbet G. Pikuła, Katarzyna Jagielska i Joanna M. Łukasik, 31-56. Kraków: Wydawnictwo Scriptum, 2020.

Makaruk, Katarzyna, Joanna Włodarczyk, Renata Szredzińska. „Negatywne doświadczenia młodzieży w trakcie pandemii. Raport z badań ilościowych”, Fundacja Dajemy Dzieciom Siłę. Dostęp: 24.05.2021. https://fdds.pl/_Resources/Persistent/5/0/0/e/500e07 74b 0109a6892ce7 77b0d8595f528adea62/Negatywne-doswiadczenia-mlodziezy-w-trakcie-pandemii.-Raport-zbadan-ilo sciowych-1.pdf.

Poleszak, Wiesław, Jacek Pyżalski. „Psychologiczna sytuacja dzieci i młodzieży w dobie pandemii”. W Edukacja w czasach pandemii wirusa COVID-19. Z dystansem o tym, co robimy obecnie jako nauczyciele, red. Jacek Pyżalski, 7-15. Warszawa: EduAkcja, 2020.

Ptaszek, Grzegorz. „Słowo wstępne”. W Edukacja zdalna: co stało się z uczniami, ich rodzicami $i$ nauczycielami?, red. Grzegorz Ptaszek, Grzegorz D. Stunża, Jacek Pyżalski, Maciej Dębski, Magdalena Bigaj, 5-6. Gdańsk: Gdańskie Wydawnictwo Psychologiczne, 2020. 
Pyżalski, Jacek. „Ważne relacje uczniów i nauczycieli w czasie edukacji zdalnej”, W Edukacja zdalna: co stało się z uczniami, ich rodzicami i nauczycielami?, red. Grzegorz Ptaszek, Grzegorz D. Stunża, Jacek Pyżalski, Maciej Dębski, Magdalena Bigaj, 112-123. Gdańsk: Gdańskie Wydawnictwo Psychologiczne, 2020.

\title{
SAMOPOCZUCIE RETROSPEKTYWNE A SAMOPOCZUCIE REALNE UCZNIÓW W CZASIE PANDEMII
}

\author{
S t r e s z c z e n i e
}

Pozytywny stan samopoczucia w wymiarze psychicznym, fizycznym i społecznym pozwala na postrzeganie życia jako satysfakcjonującego i szczęśliwego. Przejście szkoły na tryb kształcenia zdalnego w wyniku pandemii, wywołanej koronawirusem SARS-CoV-2, zaowocowało licznymi sytuacjami trudnymi, a te wpłynęły na samopoczucie dzieci i młodzieży. Celem podjętych badań było określenie retrospektywnego i realnego samopoczucia uczniów. Poszukiwano ponadto związku poziomu samopoczucia ze zmiennymi: płci, wieku, klasy, miejsca zamieszkania i sytuacji materialnej.

Słowa kluczowe: samopoczucie; edukacja zdalna; pomoc psychologiczno-pedagogiczna; pandemia. 